OPINION

OPINIÃO

Keywords:

present value, budget impact analysis, robotic assisted surgery

\section{Net Present Value as an instrument to simplificate the decision making process in health technologies economic evaluation}

\author{
O Valor Presente Líquido como instrumento de \\ simplificação do processo de tomada de decisão nas \\ análises econômicas de tecnologias em saúde
}

Tânia Maria Costa da Silva Beume

DOI: 10.21115/JBES.v8.n1.p65-70

\begin{abstract}
Objectives: The study aims to highlight the Present Value (PV) as a financial analysis tool which could simplify the decision making process of introducing health technologies. The financial evaluation can be extended as necessary, including outcomes and utility. As a model, the instrument was applied to the economic analysis of a robotic-assisted surgery equipment acquisition at José de Alencar Gomes da Silva National Cancer Institute (INCA - Ministry of Health - Brazil). Methods: The economic analysis of a robotic-assisted surgery equipment acquisition in an institute for oncology using the PV. Quantitative data was simulated to allow the development of an economic model, considering prostatectomy as a basis. The PV was calculated using MS EXCEL ${ }^{\oplus}$. The results allowed us to formulate the goals of a Budget Impact Analysis (BIA) or other health economics evaluation within the process of public choice in a Beveridge model health care system. Results: The PV in this model was positive. Data collection and processing was simple and extrinsic macroeconomics variables, such as inflation and change, were important to reflect their impact to the budget. Cost information reflected the local market. A negative PV provided information on the financial resource amount to introduce technology by justified use. Conclusions: The PV has proved to be a useful and robust instrument to evaluate financial risks, especially those related to the introduction of a recent technology. This financial perspective as performed helped to set the goals of a societal perspective in a unified health care system through the health economics evaluation.
\end{abstract}

\section{RESUMO}

valor presente, análise de impacto orçamentário, cirurgia robótica
Objetivos: O trabalho procura oferecer uma visão sobre a aplicação do valor presente (VP) como um instrumento de análise financeira que poderia simplificar o processo de tomada de decisão para a introdução de tecnologias de saúde. A partir do resultado da análise financeira, o processo de tomada de decisão poderá ser ampliado de acordo com a necessidade, incluindo as análises sobre desfecho e utilidade. O modelo descrito foi utilizado como instrumento de avaliação econômica da aquisição do equipamento de cirurgia robótica no Instituto Nacional de Câncer José Alencar Gomes da Silva (INCA - Ministério da Saúde - Brasil). Métodos: Análise econômica da introdução de equipamento de cirurgia robótica em um instituto de atenção oncológica, utilizando o valor presente. As informações quantitativas foram simuladas para permitir o desenvolvimento do modelo econômico, considerando o procedimento de prostatectomia. O valor presente foi calculado com o au-

Recebido em: 21/12/2015. Aprovado para publicação em: 15/03/2016

1. Division of Planning - José de Alencar Gomes da Silva National Cancer Institute (INCA - Ministry of Health - Brazil). Member of the German Society for Quality Management in Health Care and Patient Safety (GQMG). Member of the Brazilian Society for Health economics - AbrES. Member of the International Health economics Association - iHEA.

Institution: Division of Planning at José de Alencar Gomes da Silva National Cancer Institute (INCA - Ministry of Health - Brazil).

Funding: This study received no funding.

Conflict of Interest: The author disclosed no conflicts of interest.

Congress where the study was presented: The work was presented in a poster format during the XI National Meeting of Health economics / Economics VI Congress of Health in Latin America and the Caribbean in São Paulo in September 2014. The summary is found published in the Conference Proceedings (available in http://abresbrasil.org.br/anais-abres.html),

Corresponding author: Tânia Maria Costa da Silva Beume, Division of Planning, José de Alencar Gomes da Silva National Cancer Institute, Rio de Janeiro (RJ), Brazil. +55 21 3207-4619. E-mail: taniambeume@yahoo.com.br 
xílio do programa MS EXCEL ${ }^{\circledast}$. O resultado possibilita a formulação dos objetivos de uma análise de impacto orçamentário (AIO) ou a de outra avaliação de econômica em saúde dentro do processo de escolha pública em um sistema de saúde do tipo Beveridge. Resultados: No modelo apresentado, o valor presente foi positivo. Foi fácil levantar e manusear as informações e as variáveis econômicas extrínsecas como inflação e taxa de câmbio se deixam refletir na determinação das necessidades orçamentárias. Informações sobre custo refletem o mercado onde estará sendo utilizada a tecnologia. Um valor presente negativo irá oferecer informação sobre a necessidade orçamentária para introdução da tecnologia no caso de utilidade relevante para a sociedade. Conclusões: $O$ valor presente comprovou ser uma ferramenta robusta e útil para avaliar o risco financeiro, principalmente na introdução de tecnologias pioneiras. Da maneira como é analisada a perspectiva financeira, facilita a determinação de objetivos relacionados à perspectiva social dentro de um sistema universal de saúde e que poderão ser acoplados a avaliação econômica de saúde.

\section{Introduction}

For the last two decades, Health economics became indispensable to better allocate scarce resources in health care systems. The incremental economic analysis in health care offers information for the decision making process, mainly for the introduction and management of public health care policies, research and prevention. The health economics analysis considers variables related to utility and outcome, which in the Beveridge model Health Care System with the characteristics of the Brazilian Unified Health System (SUS) are usually not so easy to identify, measure or analyze for a longer period of time. For this reason, decision making has become too complicated, and often brings irreversible consequences, including an overcharge, not only budgetary but also for the sustainability of public health programs and stable hospital assistance. In general, health care institutions, mainly the ones that belong to public health systems, use the Budget Impact Analysis (BIA) or/and Mini-Health Technology Assessment (Mini-HTA) for economic evaluation and usefulness to introduce or remove a health care technology.

The BIA considers the PV in one to five periods, but no clinical outcome (Ireland, Health Information, and Quality Authority, 2010), (AL Ferreira da Silva et al, 2012). Some medical technologies in the oncology field have a wider lifespan.

Health economics analysis - with emphasis to the Mini-HTA, that was designed to be simple, precisely to favor the decision making process in health care - ponder wide time frame since it adds clinical outcome, ethical value, social data, and subjective variables, such as quality of life. BIA has the advantage of making data collection and health technology's introduction (medicine, technical, process or equipment) more agile, since it only contemplates cost information. An analysis of cost effectiveness (ACE) is recommended (Ireland,
Health Information and Quality Authority, 2010). However, since the economic cost is an opportunity cost, the BIA is not complete: relevant costs, such as depreciation, are not contemplated, and revenue is not included as well. Similarly, the market situation is not contemplated, posing a risk for sustainability in the future. This study shows how a financial investment analysis could be useful to the economic analysis in health care: The PV was used in the same way as it was used in the financial environment, to facilitate considerations about risk, improve the chances of a project, and later, make some space for the consideration of expected clinical outcomes and public choice related aspects.

PVs and other dynamic financial analysis are financial tools to help investment-related decision making, and they take into account the revenue and cost during the economic life cycle of an investment (Perridon L, Steiner M, 2004). Even in a public health care setting, the production must be seen as revenue, and all projects in public health have an economic time period. These aspects are usually not enrolled in health care economic decisions in public health systems.

Through the PV, the monetary value of the investment is discounted considering the market interest rate, since the last period to the present date precisely demonstrates the advantage or disadvantage of the investment, unlike the statics financial analysis, which only offers median values (Perridon L, Steiner M, 2004). All other modalities of the dynamics investment analysis could be safely used in health care, especially by public health systems, since these decision making modalities offer more transparency and accuracy concerning the budget management. Besides, the information is easier to collect than with the BIA, and this fact could make this economic evaluation to become popular in the daily decision making within the health care system.

The investment analysis suggested in this paper represents the first step of a more complex decision making, if necessary. This implies that the result showed through these initial calculations could help health care managers to establish more subjective goals related to the outcome and utility for the patients and for the health care system, since resources are scarce and public. This first economic view in a public and universal health care system could clarify that the acquired right to access a technology has a budgetary limit, and this could avoid the introduction of a health technology without value for money under a societal perspective, besides possibly setting a limit to the acquired right (Franken Margreet et al., 2014).

The English experience by Raftery J, 2014 shows that only $16 \%$ of all technologies submitted to a cost effectiveness analysis were not recommended. In other words, this could imply that the focus on utility and outcome could recommend a technology and, at the same time, introduce a budget bottleneck. 
Cost information is extremely necessary to get effective results in health economics, and health care institutions experience difficulties in implementing cost systems. For health care staff, the registering of economic information is still a myth. This is a burden for health economics, since organized information about drugs and medical supplies consumption constitute the basis of every health economics evaluation, as well as, for the managers and controllers in health care.

Health economic evaluation using the VP aims to facilitate the process of decision making when introducing or removing health technology in the diagnosis, treatment and prevention of diseases. The first financial evaluation helps to define the social value to be reached through the technology implementation, since the manager has a financial basis to add and set goals whose usefulness is difficult to measure.

In this study, the author applied the PV to analyze a robotic-assisted surgery equipment acquisition, since this technology is extremely recent and can emphasize the method. In either way, an example using PET-CT could be useful as well.

\section{Objectives}

To evaluate the use of the dynamics financial investment analysis in the context of health care in a public health system in an attempt to simplify the health economics evaluation. The PV was applied to the economic evaluation of a robotic-assisted surgery equipment acquisition in a public institute for cancer research and treatment; a pioneer technology.

\section{Methods}

The Da Vinci robotic-assisted surgery equipment was acquired by José de Alencar Gomes da Silva National Cancer Institute (INCA), in 2011.

The economic model in this study considered at first the calculation of the PV using financial data based on the present review of the literature (Barbash IG and Glied SA, 2010) and information available in the marketplace for medical technology, considering international publication describing consumption experience and direct cost in the center of oncology in the United States of America and Germany (Andrews M, 2013). This phase evaluated the financial sensibility concerning this investment as it could be in any other branch: the parameter used in health economics evaluation was not introduced.

All financial values are based on the present review of the literature and are sometimes adapted for the effect of an economic model.

For the calculation, we used MS - Excel ${ }^{\oplus}$.

Concept: The present value (PV) is a dynamic financial analysis used for the decision making process between two or more alternative investments: the most beneficial invest- ment will present a positive PV (Perridon L, Steiner M, 2004). Likewise, the health economics evaluation by VP is considered more than one alternative.

For this study, the PV was contemplated; however, there is no impediment to using any other dynamic financial analysis.

$\mathrm{ROI}$ (Return of Investment) is considered the total of necessary surgeries to return the investment.

Depreciation cost was calculated from the first year of the life cycle and it was considered that this cost was also enrolled to stipulate the revenue, as usually done in accounting. The calculation took into account the geometric decreasing method, since the technology is a pioneer and the application of intensive depreciation in its first years is indicated. The financial evaluation could also consider the following points:

- How much time is needed for the machine preparation for a new procedure?

- What was the surgery forecast before acquisition?

- How much time is needed for technical review?

- What type of maintenance contract: foresees compensation of the day off?

- And what about the environment impact of the components disposal?

- What is the potential macroeconomic scenario to ensure the supply and technical sustainability (imported technology)?

\section{Economic evaluation using the present value}

Considering the absence of robust financial information at the time of the analysis, the following economic information was included as assumptions:

- The market value of the disbursement of acquisition: US\$ 2,500.00 ( $=\mathrm{R} \$ 5,750.00)$

- Market value of the maintenance contract: US\$ 200,000.00 ( $=R \$ 460,000.00$ )

- Market value for the supplies based on the literature: US\$ 1,500.00 ( $=\mathrm{R} \$ 3,450.00)$

- Regarding the information related to income form considered the revenue figures of private hospitals in Brazil published in the hospitals websites (Hospital Fee Schedule) for service of robotic prostatectomy: $\mathrm{R} \$ 27,825.00$.

- A profit margin of 0.3 considered.

- The dollar price of US\$2.30 (2.2882 rounded to 2.30) considered in 08/08/2013!.

- Depreciation Method: Geometric decreasing method changing to the linear method from t4 on. This method is indicated for top equipment; however, it is not accepted by fiscal authorities in Brazil. The degressive geometric method depreciates the asset intensively in the early years 
Table 1. Shows the financial evaluation considering the following assumptions

\begin{tabular}{lccc}
\hline & $\begin{array}{c}\text { Value in } \\
\text { US\$ }\end{array}$ & $\begin{array}{c}\text { Value in } \\
\text { BRL }\end{array}$ & $\begin{array}{c}\text { Economic } \\
\text { life cycle }\end{array}$ \\
\hline $\begin{array}{l}\text { Total Value of the } \\
\text { Investment }\end{array}$ & $2,500,000$ & $5,750,000$ & \\
\hline $\begin{array}{l}\text { Dollar value in } \\
\text { 08/08/2013 }\end{array}$ & 2.30 & - & \\
\hline $\begin{array}{l}\text { Economic lifespan } \\
\text { in years, according } \\
\text { to the producer }\end{array}$ & & & \\
\hline $\begin{array}{l}\text { Fixed maintenance } \\
\text { cost per year }\end{array}$ & $200,000 /$ & $460,000 /$ & \\
\hline $\begin{array}{l}\text { Estimated variable } \\
\text { and direct cost }{ }^{2} \\
\text { per surgery }\end{array}$ & year & year & \\
\hline
\end{tabular}

Table 2. Calculation of depreciation using the geometric method decreasing:

\begin{tabular}{lcccc}
\hline & $\begin{array}{c}\text { Acquisition } \\
\text { Cost/Residual } \\
\text { Value in BRL }\end{array}$ & $\begin{array}{c}\text { Lifespan } \\
\text { in Years }\end{array}$ & $\begin{array}{c}\text { Depreciation } \\
\text { share value } \\
\text { in BRL }\end{array}$ & $\begin{array}{c}\text { Depreciation } \\
\text { value in BRL }\end{array}$ \\
\hline T0 & $5,750,000.00$ & 7 & $205,357.15$ & $1,437,500.05$ \\
\hline T1 & $4,312,499.95$ & 6 & $205,357.15$ & $1,232,142.90$ \\
\hline T2 & $3,080,357.05$ & 5 & $205,357.15$ & $1,026,785.75$ \\
\hline T3 & $2,053,571.30$ & 4 & $205,357.15$ & $821,428.60$ \\
\hline T4 & $1,232,142.70$ & 3 & $205,357.15$ & $616,071.45$ \\
\hline T5 & $616,071.25$ & 2 & $205,357.15$ & $410,714.30$ \\
\hline T6 & $205,356.95$ & 1 & $205,357.15$ & $205,357.15$ \\
\hline T7 & -0.20 & & & 0.00 \\
\hline
\end{tabular}

Table 3. Transition from depreciation by the linear method in t4

\begin{tabular}{lcccc}
\hline & $\begin{array}{c}\text { Acquisition } \\
\text { Cost in BRL }\end{array}$ & $\begin{array}{c}\text { Lifespan } \\
\text { in Years }\end{array}$ & $\begin{array}{c}\text { Depreciation } \\
\text { share value } \\
\text { in BRL }\end{array}$ & $\begin{array}{c}\text { Depreciation } \\
\text { value in BRL }\end{array}$ \\
\hline T0 & $5,750,000.00$ & 7 & $205,357.15$ & $1,437,500.05$ \\
\hline T1 & $4,312,499.95$ & 6 & $205,357.15$ & $1,232,142.90$ \\
\hline T2 & $3,080,357.05$ & 5 & $205,357.15$ & $1,026,785.75$ \\
\hline T3 & $2,053,571.30$ & 4 & $205,357.15$ & $821,428.60$ \\
\hline T4 & $1,232,142.70$ & 3 & $410,714.23$ & $410,714.23$ \\
\hline T5 & $821,428.47$ & 2 & $410,714.23$ & $410,714.23$ \\
\hline T6 & $410,714.24$ & 1 & $410,714.23$ & $410,714.23$ \\
\hline T7 & 0.01 & & & 0.00 \\
\hline
\end{tabular}

of life. From the 4th period will move to the linear method that in $\mathrm{t} 7$ is fully depreciated. Tables 2, 3 and 4 show the calculation of the depreciation.

- Interest Rate (i): Selic rate 2013 (accumulated) 0.09/year.

\section{Estimated Direct Cost}

- Maintenance: R\$ 460,000.00/year

- Medical Supply for 150 procedures/year: US\$ 225,000.00 ( $=$ R\$ 517,500.00/year)

\section{Estimated Revenue according to the assumption of the study}

- Value of prostatectomy: $R \$ 27,825.00$

- Profit percentage of 0.3 considered. This percentage deducted from total revenues contemplated in the search for an approximation of the repayment table used by the Unified Health System:

- Revenue in the Model: 27,825.00-8,347.50 = 19,477.50

- Output indicator: 100 surgeries/year

- Estimated production indicator: added 0.5 considering the wide range of indications, as well as higher demand $=150$ cases/ year (demand for calculation purposes).

Table 4. Depreciation cost to be considered

\begin{tabular}{l}
\hline Depreciation \\
\hline $\mathrm{T} 1=1,437,500.05$ \\
\hline $\mathrm{T} 2=1,232,142.90$ \\
\hline $\mathrm{T} 3=1,026,785.75$ \\
\hline $\mathrm{T} 4=410,714.24$ \\
\hline $\mathrm{T} 5=410,714.24$ \\
\hline $\mathrm{T} 6=410,714.24$ \\
\hline $\mathrm{T} 7=410,714.24$
\end{tabular}

Present Value Calculation: Formula: $\mathrm{Co}=-I_{0}+\sum^{n} R^{t} / q^{t}+L^{n} / q^{n} ;$ Where: $t=1$ $\mathrm{Co}=$ Net Present Value (NPV): $I_{0}=$ Initial Investment $\mathrm{R}^{\mathrm{t}}=$ capital flow in the period (revenue-cost) $t ; L^{n}=$ residual value period $t ; q=1 /(1+i)^{n}$ where is the interest rate $=$ discount factor

Table 5. Calculation of the NPV modeling

\begin{tabular}{lll}
\hline T0 $=5,750,000.00$ & & \\
\hline T1 $=2,921,625-2,414,500,055^{*} 0,60$ & $1,472,924.97$ \\
\hline T2 $=2,921,625-2,209,640.90^{*} 0.65$ & $=1,485,358.41$ \\
\hline T3 $=2,921,625-2,004,285.75^{*} 0,70$ & $=1,518,624.75$ \\
\hline T4 $=2,921,625-1,388,214.24^{*} 0,76$ & $=1,866,582.18$ \\
\hline T5 $=2,921,625-1,388,214.24^{*} 0,85$ & $=1,741,642.89$ \\
\hline T6 $=2,921,625-1,388,214.24^{*} 0,92$ & $=1,644,467.89$ \\
\hline
\end{tabular}

$\mathrm{NPV}=$ Initial investment $-($ revenue-cost $)=T 0$ 
Estimated Revenue: $150^{*} 19,477.50=\mathrm{R} \$ 2,921,625.00 /$ year

Present Value: $R \$ 5,570,000-R \$ 9.729 .601,09=R \$$ 3.979.601,09

\section{Positive Present value}

Another example by expanding the perspective of clinical indications and the number of cases year:

Assumptions:

- Considering the same values and depreciation method

- Considering these initial maintenance contract values acquisition

Table 6. Calculation of the NPV in the second example:

\begin{tabular}{ll}
\hline T0 & R\$ 5,750,000 \\
\hline T1 & $=7,791,000.00-2,817,500.05^{*} 0,60=$ \\
& $=7,791.00-1,690,500.03=6,100,499.97$ \\
\hline T2 & $=7,791,000.00-2,612,142.90 * 0,65=$ \\
& $=7,791,000.00-1,697,892.89=6,093,107.11$ \\
\hline T3 & $=7,791,000-2,406,785,75 * 0.70=$ \\
& $=7,791,000.00-1,684,750.02=6,106,249.98$ \\
\hline T4 & $=7,791,000.00-1,790,714.24 * 0.76=$ \\
& $=7,791,000-1,390,942.83=6,430,057.17$ \\
\hline T5 & $=7,791,000.00-1,791,714.24 * 0.85=$ \\
& $=7,791,000.00-1,522,957.10=6,268,042.90$ \\
\hline T6 & $=7,791,000-1.791 .714,24 * 0.92=$ \\
& $=7,791,000.00-1,648,377.10=6,142,622.90$ \\
\hline
\end{tabular}

$\Sigma \operatorname{Re}-\mathrm{Cu}{ }^{*} 1 /(1+\mathrm{i}) ; \mathrm{t}-1$.
- Increase in direct costs in proportion to the increased production that goes on to consider 400 cases/year.

- Direct costs: R\$1,380,000. - Annual Revenue: $\mathrm{R} \$ 7,791,000$

$\mathrm{VP}=37.140 .580,03-5,750,000=$ $=\mathrm{Co}=31.390 .580,03 \mathrm{BRL}$

The present value is positive.

\section{Discussions}

Considerations used to calculate PV in this model:

- The depreciation method shows the impact brought by the depreciation for the return of investments in technology. The used method reflects the uncertainty about the speed of technological progress.

- The chosen type of surgery has a lower demand within the range of indications for robotic surgery and especially in the examined institution.

PV for the second example is remarkably higher due to the expansion of the possibility of using the technology.

The PV identifies immediate return on investment, leaving the manager a clearer path to define medical and societal goals to be achieved.

In case of a negative $P V$, it is up to the manager to come to an agreement about the social interest for the deployment of technology, and to stipulate clinical and managerial targets that balance investment costs. As an example:

Table 7. Characteristics of the main health technology assessments and the PV

\begin{tabular}{|c|c|c|c|}
\hline Features & Budget Impact Analysis & Mini-HTA & Net Presente Value (NPV) \\
\hline Goal & $\begin{array}{l}\text { Estimates the economic impact of } \\
\text { introducing or removing a health } \\
\text { technology concerning the budget }\end{array}$ & $\begin{array}{l}\text { Lists the requirements } \\
\text { and consequences of a } \\
\text { technology introduction }\end{array}$ & $\begin{array}{l}\text { Analyzes the profitability of two } \\
\text { investment alternatives and decide } \\
\text { on the alternative whose NPV is } \\
\text { equal to or greater than zero }\end{array}$ \\
\hline Time Horizon & 12 months & Does not specify & $\begin{array}{l}\text { Specified for the duration } \\
\text { of the investment }\end{array}$ \\
\hline $\begin{array}{l}\text { Demand for } \\
\text { Economic } \\
\text { Information }\end{array}$ & $\begin{array}{l}\text { Affected Population, only } \\
\text { direct medical cost }\end{array}$ & $\begin{array}{l}\text { Estimated cost and } \\
\text { benefit information }\end{array}$ & $\begin{array}{l}\text { All direct costs involving the } \\
\text { technology introduction, including } \\
\text { estimated revenue and depreciation }\end{array}$ \\
\hline Discount & 0.05 & 0.05 & Market interest rate \\
\hline Criticism & $\begin{array}{l}\text { Does not include the investment } \\
\text { first; discount rate does not reflect } \\
\text { macroeconomic conditions in the } \\
\text { region where the technology will be } \\
\text { applied; time horizon is too short; } \\
\text { demand for information is intense. } \\
\text { Does not report clinical outcomes. }\end{array}$ & $\begin{array}{l}\text { Does not include the investment } \\
\text { first; discount rate does not reflect } \\
\text { macroeconomic conditions in the } \\
\text { region where it is being applied to } \\
\text { technology; time horizon is reduced; } \\
\text { demand for information is intense }\end{array}$ & $\begin{array}{l}\text { Market interest rate reflects } \\
\text { macroeconomic impacts, initial } \\
\text { need for less intense information } \\
\text { than incremental analysis of health } \\
\text { economicss. For health technologies, } \\
\text { a broader time horizon allows } \\
\text { to realize more robust benefits. } \\
\text { The geared initial calculation for } \\
\text { investment only facilitates the design } \\
\text { of targeted goals for the benefit } \\
\text { and clinical results to be achieved. }\end{array}$ \\
\hline
\end{tabular}


Monitor the reduction of blood product consumption during surgery.

Increase the turnover of operating rooms to increase the number of surgeries.

The use of the PV offers a view of institutional needs and the point to be working to make the investment interesting for the economic and social perspective, as well as easier and more objective, mainly by public resources.

As an example, in oncology the following clinical parameters will guide the completion of the financial analysis considering the robotic assisted surgery:

Will the access to compromised areas in younger patients and in earlier stages favor the reduction of the disease's social costs?

Will the reducing of harm provide a faster integration of the patient to his/her social environment, reducing costs with reconstruction therapies and psychosocial integration?

The calculation of the PV was effective and fast to drive decision making and also to draw attention to the investment return to society. It also makes clear the impact of direct costs, in this case, the consumption material import costs subject to currency fluctuation. The use of BIA - contemplating only one period - could rule out the deployment of the technology by not foreseeing the expansion of its use, or it could facilitate the deployment by excluding the impact of aspects related to the costs of replacement investment among others.

This analysis also supports both technology introduction decisions and replacement, shielding those involved in making media harassment around the decision, producers and manufacturers, in addition to the own internal user of health institutions. In the foreground, a dynamic analysis of investment has already defined whether or not the investment will be beneficial from an economic point of view. The remaining parameters to be considered will be associated with the analysis according to the goals to be achieved in terms of strategic planning of the public health program management.

The information collected at this moment is not nearly as exhausting and may consider the contractual vendor proposal.

\section{Conclusions}

The study aimed to demonstrate the possibility of using more simplified analysis for decision making and health technology assessment. The financial analysis aimed to evaluate a technology for health promotion and protection, as well as, for the social welfare. The innovative nature of the evaluated technology lacked the database for conducting a robust economic analysis to assist in the decision making, using the incremental analysis of health economics. Economic information for the analysis of cost effectiveness was not available at the time of the study, and it is still in progress in many countries. The PV proved to be easier and used information in a way that could help the health care manager to establish goals considering ethics, safety, reimbursement and usefulness as parameter for health economics considerations. The PV also offered a complete perspective on the use of resources and budget impact, both aspects that are too important to report to the society in an universal health system. The financial analysis, as a first stage of health economic evaluation, can represent the macroeconomics of the region where the technology will be introduced, since it considers variables as change tax and inflation. These aspects are usually not included in the evidence used for health economic evaluations.

\section{Acknowledgements}

To fellow Elaine Moutinho from the Planning Division at José de Alencar Gomes da Silva National Cancer Institute, thank you for your feedback.

\section{References}

BRAZIL. Ministério da Saúde. Diretrizes Metodológicas: Análise de Impacto Orçamentário. Manual para o Sistema de Saúde no Brasil - MS - Brasília - DF 2012.

IRELAND. The Ministry of Health. Health Information and Quality Authority. Guidelines for the Budget Impact Analisys of Health Technologies in Ireland. https://www.hiqa.ie/publications/guidelines-budget-impactanalysis-health-technologies-ireland. Accessed on: 03/23/2016

Ferreira-da-Silva AL, Ribeiro RA, Santos VCC, Elias FTS, d'Oliveira ALP, Polanczyk CA. Diretrizes para análise de impacto orçamentário de tecnologias em saúde no Brasil. Cadernos de Saúde Pública 28 (7):12231238, jul 2012

Perridon Louis, Steiner Manfred. CorporateFinanz.Finanzwirtschaft der Unternehmung. 13 Edition. ISBN 3-8006-3112-1. Munich. Verlag,Vahlen.2004.

Franken M, Koopmanschap M, Steenhoek A. Health economics evaluations in reimbursement decision making in the Netherlands: time to take it seriously? Evidenz, Fortbildung und Qualitat im Gesundheitswesen (2014) 108, 383-389.

Raftery J. Health economics evaluation in England. Evidenz, Fortbildung und Qualitat im Gesundheitswesen (2014) 108, 367-374.ortbildung und Qualitat im Gesundheitswesen (2014) 108, 383-389.

Barbash IG, Glied S. New technology and Health Care Costs - the case of Robot Assisted Surgery. The New England Journal of Medicine 368;8;701-704.

Andrews M. Questions arise about robotic surgery cost effectiveness. Kaiser Health News. April 23, 2013. Available in http://khn.org/news/042313michelle-andrews-robotic-surgery. Accessed on: 08/23/2013. 